\title{
Pedagogy for personal transformation: \\ Faith development in the context of a Scottish Baptist College ${ }^{1}$
}

\section{Ian Birch, Lina Toth and Graham Meiklejohn}

All three authors serve at the Scottish Baptist College. Rev Dr Ian Birch specialises in historical theology and biblical studies and is the Principal of the College. Rev Dr Lina Toth (Andronoviene) is a practical theologian with a second specialism in history, and is the Assistant Principal. Dr Graham Meiklejohn serves as Lecturer in Theology, with special interest in doctrinal and practical theology.

\section{Introduction}

'Just be careful that your theological studies don't change you and your faith!' It is not uncommon for a student to hear this or similar advice from a well-wisher as they embark on their theological studies at the Scottish Baptist College (SBC). Some students testify to feeling fearful of change that could be brought about by undertaking theological education. And, indeed, it may be justified: many graduates would speak of their personal transformation as one of the most significant aspects of time spent at SBC.

At this point, a few words of introduction about our context are in order. Founded in 1894, SBC is a small independent college providing a Bachelor of Divinity in Theology with Pastoral Studies programme which can be undertaken full- or part-time. It also offers some additional stand-alone modules. The programme is delivered by SBC in collaborative partnership with the University of the West of Scotland on its Paisley campus, where the College is located. Its original 
purpose was exclusively to train candidates for ministry in Scottish Baptist churches, and the key competences for ministry required by both the Baptist Union of Scotland (the College's primary vocational partner) and the Baptist Union of Great Britain are integrated into the overall learning experience of the BD programme. However, currently the programme also serves the educational needs of a wider Christian public - students from other denominations as well as those from the Baptist background interested in a whole range of vocational outcomes (teaching, chaplaincy, para-church organisations, caring professions, bi-vocational ministry and further study). ${ }^{2}$

The expectations of such a diverse student body are inevitably wide-ranging, but the aforementioned fear - of failing to succeed in the academic study, and also of the prospect of transformation lying ahead - is a common experience. Interestingly, the trepidation surrounding the study of theology is articulated by people from all sides of the theological divide. It is not uncommon that Reformed believers speak of their dread of being transformed into Arminians and vice versa, paedobaptists worry about being forced to adopt believer's baptism, non-Baptists of indoctrination into Baptist 'ways,' and evangelicals resisting every suggestion of a social Gospel, as do liberals of fundamentalism. Thus in one of the first conversations during the induction of new students we try to explain that we have no hidden agenda for reconfiguring their worldviews in a specific way contentwise. We do, however, see the personal, convictional transformation of our students as a tacit goal of our teaching. In this paper, we would like to offer and explore several ways of understanding such pedagogy for transformation through theological education. Firstly, we will propose a theological interpretation undergirding our teaching and learning ethos. Secondly, we will offer some insights arising from Transactional Analysis.

\section{Theological education as convictional transformation}

An individual and institutional approach to teaching theology will be dependent on a particular understanding of what theology is. One of the helpful perspectives that has been influential in forming the 
ethos of SBC is convictional theology, first formulated by a Baptist theologian, James Wm. McClendon, ${ }^{3}$ and since then developing a significant attraction by a number of Baptist schools and theologians. ${ }^{4}$ Convictional theology is committed to careful attention to deep-seated persuasions, feelings and motives that shape and direct human lives. McClendon describes it as a three-fold task of theology: description, interpretation and transformation of 'the convictions of a convictional community, including the discovery and critical revision of their relation to one another and to whatever else there is. ${ }^{5}$ Importantly, 'convictions' are rarely verbalised. Rather, they become most visible in daily living, in the things and practices we choose to spend our time or money on, and the loyalties and interests these choices reflect. ${ }^{6}$

Thus, our actual convictions may be difficult to recognise or define explicitly because they are not typically reflected upon in an intentional way. More than that, an assumption is often made that the professed beliefs of the student and their community of faith are indeed their actual convictions. To give a couple of illustrations, whilst a student would likely have no trouble in affirming the doctrine of creation and professing their belief in God as the Creator of a good earth, a different picture emerges when questions are asked about the expression of this doctrine in the everyday life of the student and their faith community. The behaviour of most of us (perhaps all of us?) more often than not communicates a blatant disdain for creation, and by implication its Author, suggesting a rather different operative theological map which arises out of a particular reading of Scripture. Likewise, students may initially assent to a belief that suffering is used by God to cultivate or chastise a Christian, but when faced with the reality of mass suffering by innocent by-standers, they may begin to recognise the complex implications of such a belief. ${ }^{7}$ Or again, while students strongly affirm the incarnation of the Son of God as a physical, bodily event, and the death of Jesus as the crucifixion of his body (no Docetism here!) they do not always recognise the implications of this for the message of the Gospel which has as much to do with healing, preserving and nourishing bodies as saving souls.

In contrast to opinions or preferences, convictions are an essential part of who we are and therefore are not altered easily. Undergoing 
a significant convictional change means becoming a significantly different person. It is in this context that a profound change of convictions can be called a 'conversion'. ${ }^{8}$ As Darrell L. Guder has helpfully noted, rather than a once-in-a-lifetime event, there is a need for a continuing conversion in the life and ministry of the church, ${ }^{9}$ and the same kind of expectation of continuing conversion can be said to characterise theological engagement. It should be necessarily selfinvolving and therefore transformational.

\section{Professed versus owned convictions}

The disconnect between a theology that is taught, professed or preached and one that is lived out practically, and/or described by people without much or any theological education has been gaining an increasing interest recently. ${ }^{10}$ Thus, in sociology of religion, researchers talk of 'lived religion'. ${ }^{11}$ Practical theologians often employ the terms 'ordinary', 'pastoral' or 'lived' theology. ${ }^{12}$ Some other theologians call it 'primary' or 'first-order' theology as a way of distinguishing it and exploring it in relation to doctrinal, systematic or academic 'secondary' or 'second-order' theology. ${ }^{13}$

The approach of the College to the teaching and learning experience aims to transition students from the state in which their personal faith aspirations - the convictions they desire to hold - are dependent on the authority and trustworthiness of significant others, to the point where such convictions have been consciously reflected upon and tested.

As a starting point for considering such transformation we want first of all to reflect on some of the obstacles to the process of faith development. First, we have already observed that a number of adult learners in the field of theology and religious studies have not been encouraged to question or think too deeply about the faith they have inherited. In fact, they may have been positively discouraged by friends and church members in their wish to enrol in theological studies. At a deeper level, we have observed that in the usual church teaching contexts, such as sermon or Bible study, there operates an implied chain of power and authority which suppresses the thinking and questioning of hearers regarding the information in play. The 
chain of authority at work in these events has God as the source of revelation and truth about the divine and all things spiritual. God is viewed as the author of the Bible, the repository of authoritative information about the divine nature and subsidiary matters concerning human relating to the divine. This book of truths about God and the virtuous life God requires, nourishes sermon preparation and delivery which those qualified and appointed to the task perform on behalf of the religious community. Sermons and Bible studies are therefore seen to be delivered by 'experts' to the 'non-experts'. ${ }^{14}$

The same kind of model then can be applied to theological education: something that originated with God, was mediated through the Bible, and in the here-and-now has been relayed by the biblical scholar or theologian, and is therefore not subject to critical analysis, contradiction or even refinement, since to question this word is to question God. The consequence of this arrangement is the passivity of Christian learners at the hands of Christian teachers. Of course, this is not unique to the Christian world and Christian education: 'the sage on the stage ${ }^{15}$ model has been deeply ingrained in much of traditional Western education, even though it is being increasingly, and swiftly, challenged and replaced by other, more helpful paradigms. ${ }^{16}$ However, when the sage on the stage has God in the wings as the ultimate author of the manuscript, there is an especially powerful dynamic at work.

One of the first tasks we find ourselves commonly undertaking at SBC is to assure students new to theological education that critical thinking is not a negative or deconstructive enterprise, but a legitimate and necessary activity for anyone who wishes to wrestle with theological matters. We speak of critical thinking as a 'discipleship of the mind' which is not in conflict with loving God with heart or soul, but a responsible activity for those who wish to be leaders in a faith community where people are often wrestling with God's hiddenness in a world of suffering and pain, as well as joy. ${ }^{17}$ It is a kind of pedagogy that empowers the student to face the challenge of forming their own convictions, and also to begin to understand the convictional framework of others, including the teacher. The latter is not simply an expert, or a 'sage', but a fellow, though hopefully more experienced, traveller on the Way. ${ }^{18}$ This allows for a different 
engagement with the teachers that is not based on the power dynamics of the teacher-student relationship.

\section{Transactional Analysis and transformational pedagogy}

At this point, we would like to consider some further ideas about the way in which students interact with teachers by turning to a different field and considering the process of educative relationship from the perspective of Transactional Analysis (TA). TA is an approach initially developed in the 1950 s by Eric Berne, a doctor specialising in psychotherapeutic treatment, who devised a series of models to explain how people develop, make sense of their experience, and interact with others. ${ }^{19} \mathrm{TA}$ is a means of describing a set of feelings, thoughts and behaviours which capture three observable ego-states of a person under the headings of Child, Parent, and Adult. ${ }^{20}$ Briefly stated, the Child ego-state refers to a person (irrespective of age) replaying the patterns of thoughts, feelings and behaviours arising from their childhood experience. ${ }^{21}$ The Parent ego-state is the absorption of thoughts, feelings and behaviours learned from, or taught by, a parent or another figure of authority. In the Adult ego-state, a person is responding to the present reality as experienced in the here-andnow. Berne characterised the Adult ego state as 'an autonomous set of feelings, attitudes and behavior patterns which are adapted to the current reality. ${ }^{, 22}$ What is important to note about this state for our purposes is the emphasis on 'autonomy': in the Adult state, a person is thinking, feeling and acting in a manner appropriate to the current reality. ${ }^{23}$

TA has been used extensively in educational contexts to understand behavioural issues and classroom conflict, ${ }^{24}$ and provides a psychodynamic perspective on the relational aspects of teaching and learning. ${ }^{25}$ We want to use the insights of TA to consider how teachers can develop strategies of interaction with students in the classroom that encourage students to examine their convictions, reflect on their own faith development and engage with new ideas: in other words, cultivate a pedagogy for transformation. 


\section{Adapted Child in students}

The Child-ego state can take several forms. According to Berne, the Adapted Child is 'the one who modifies his behaviour under the Parental influence. ${ }^{26}$ The Adapted Child ego state is a replaying of rules-based habitual behaviours learnt as child $^{27}$ in order to respond to the expectations of parent figures in a way that generates approval or avoids censure. ${ }^{28}$ As a grown-up, a student (regardless of age!) may replay these patterns in the way they relate to the teacher and/ or the authority figure, or the author of study material the student is given. In theological education this kind of dynamic becomes evident when a teacher is touching upon a student's convictions by the use of interrogative questions, and the student is calculating what they think the teacher wants to hear, or what will be affirmed by their classroom peers. Displaying the 'right' convictions (i.e., giving the 'right answers') will be their primary concern, though of course there may be a tension between their true convictions and those presented.

The student who functions in Adapted Child may also experience an internal conflict between seemingly different messages and expectations of several authority figures. The truths presented by the minister and congregation during the student's formative years of faith, and the new approach taken by their current teacher(s) of theology, or indeed between several teachers arguing for diverse points of view can generate internal tension. For example, a suggestion that the miraculous healing of the Gerasene demoniac in Mark 5:1-20 may be read as a story of severe mental illness ${ }^{29}$ might present a painful dissonance to a student in Adapted Child state whose early authority figures have taught them rules for a strict literal reading of Scripture, and which in this instance would be an account of Jesus confronting demonic possession. A particular student's childhood culture in which the word of the preacher/teacher was 'true' and 'unquestionable' would determine their response as an Adapted Child, providing the rules for thinking about the Scripture.

TA also speaks of a Free Child (sometimes also called Natural $\mathrm{Child}^{30}$ ) mode - an uncensored Child ego-state arising out of childhood behaviour which is not dependent on following a particular set of 
rules, but on natural child reactions to the environment (such as being upset, confused, or happy), or autonomous forms of behaviour such as rebelliousness or self-indulgence. ${ }^{31}$ From an educational perspective, it is important to be mindful of the Free Child ego-state as a source of uninhibited creativity which can play a powerful role in clarifying and transforming one's convictions. ${ }^{32}$ Of course, this presupposes a safe, respectful and collaborative environment. Such an ethos is more easily felt than described, but once they are in it, students can gradually build confidence that the world does not collapse when they question or review inherited opinions, and start developing and testing convictions which are somewhat more reflected.

\section{The teacher as Child, Adult, and Parent}

Turning from the reflection on what a student might bring to the classroom in terms of psychological predisposition for learning, Transactional Analysis poses questions for what a teacher might also bring in terms of ego states to the process of education. First, it is important that a teacher would be able to recognise both forms of the Child ego-state we have discussed above in order to facilitate unblocking barriers to learning that otherwise inhibit potential for transformation. This, however, requires of the teachers themselves an ability to recognise and operate in all their own ego-states, for all these will be required to maximise the learning potential of students. This brings us to the question of how the relationship between teacher and learner can be informed by TA. For example, much of the time the teacher may operate in the Adult state, modelling problem-solving for the students as good practice as well as building their trust as a reliable guide on the students' theological journey. There may be certain times when a Free Child state may be appropriate as the teacher experiences and expresses an immediate emotion of happiness, perhaps, and by doing so models appropriate vulnerability. At other times, however, the teacher will be required to shift into a Parent state. This may happen when some students are dominating class discussion, intimidating others or acting as superior in knowledge or experience (i.e., adopting a Parent ego-state themselves). In such situations convictional and 
personal transformation of the rest of the students can be easily stifled as the more diffident members of the class withdraw into a 'safe place' of non-engagement. Or, alternatively, there may be students panicking about their ability to pass the module ('I will never understand hermeneutics!' or, 'I should not have even attempted to preach!') which calls for reassurance and guidance which some other students may not require.

In such a setting, the teacher in the Parent ego-state will need what is described in TA as 'functional fluency' - an ability to function either as a 'Controlling Parent' or a 'Nurturing Parent' as required (sometimes also called 'structuring' versus 'nurturing' functions of the Parent ego-state). ${ }^{33}$ Otherwise, there is a risk of the teacher operating in the Parent state as a reaction to the students casting them as a Parent figure, replaying their own past. ${ }^{34}$ For instance, in the 'Controlling Parent' function, a teacher may be putting a student down, or seeking to overly control the learning environment. ${ }^{35} \mathrm{~A}$ teacher as a "Nurturing Parent' may rush to help a student before determining whether help is really needed, thereby stifling opportunities for growth and the student's own necessary wrestling with their own convictions, as well as those of others.

In the context of theological education, we recognise the temptation to adopt the Controlling Parent state as a default in relation to students. It can be attractive because it maintains the power imbalance and the illusion of a relationship of expert and novice, one who has all to give and one who is passive receiver. Operating primarily in the Controlling Parent state often suggests an unhealthy lack of security on the part of the teacher which will not likely foster an environment for convictional transformation.

\section{Pedagogy for transformation: Adult to Adult}

One of the functions of our teaching, as we understand it at SBC, is to enable students to function in the Adult state. The Adult state is marked by 'autonomy', which in terms of TA 'implies clear thinking and effective problem-solving. ${ }^{36}$ Autonomy is taking responsibility for the self, taking responsibility for one's own convictions, values 
and commitments, especially faith commitments in our sphere of education. To return to the language of convictional theology, it is about the student being enabled to recognise and interpret their own convictions as well as those of their church, and in the process, to be challenged to alter some aspects of their convictional set as a response to the call to continuing conversion, personal and corporate. In TA, behaviour associated with the Adult state is organised by the deployment of the student's grown-up resources.$^{37}$ In the Adult state a student also has available to them strategies for reality-testing and problem-solving as a grown-up person, which does not exclude the Child and Parent ego-states but allows for instinctive attentiveness, assessment and evaluation of those ego-states.

How then do we help students attain autonomy in relation to their convictions, and what does autonomy mean in this context? Berne spoke about the attainment of autonomy by throwing off the Child and Parent ego-states. Notably, this is not achieved once-and-for-all, but by a continuous wrestling against past influences and pressures to external conformity. ${ }^{38}$ Freedom from traditions or convictions seemingly imposed upon us, as opposed to traditions or convictions we may have chosen to follow and embrace, comes through the cultivation of particular capacities, such as awareness. ${ }^{39}$ Awareness for Berne is the ability to know things for yourself without the encumbrance of some authority figure telling you how to interpret experience or how to configure information. Consider the case of a theology student who has sat under the preaching of ministers for many years, and comes to theological study hearing in their head the words, interpretations, convictions of a Bible teacher every time the teacher asks, 'And what do you think about this text?' Awareness is not forgetfulness of what one has learnt in the past, but the ability to hold past instructions in abeyance as one tries to hear, see and think for oneself in the present moment, with the data available here and now, in order to arrive at one's own convictions.

Among the influences which can prevent a student from achieving autonomy through awareness is, of course, the teacher. In order to encourage the student to be Adult, the teacher too must function in an Adult ego state, in which they offer instruction with a sense of 
provisionality and negotiability. In theological education, the teacher as Adult is not threatened by the student challenging or rejecting their ideas; in fact, this is welcomed as a sign of growing autonomy. The ideal we strive for in our context is a learning environment where the teacher and student are in a constructive conversation where both are open to learn and reassess their own convictions through encounter with the other.

We would want to stress that in teaching theology the attainment of autonomy is not in isolation from all that we mean by tradition and the convictions held by the past and present communities of Christian faith. It is important that teachers and students alike have the humility to listen and learn from those who went before them and those among whom they live. Autonomy, however, is the ability to affirm the convictions one holds as truly one's own not merely because a Parent figure has said that this is what one ought to believe and live.

\section{Conclusion}

It is not by accident that McClendon's Systematic Theology starts with the following sentence: 'Theology means struggle. ${ }^{40}$ Genuine willingness to examine one's convictions in the light of Scripture and the tradition of the church throughout the ages, perhaps in relation to another worldview or whatever other subject explored from a theological point of view, can feel like a struggle. That is no bad thing, for in that struggle there is an invitation to clarify, examine and transform the gap between what is 'preached' (in whatever form) and what is actually lived out. ${ }^{41}$

Students who come to SBC in many cases arrive with a rich inheritance of a 'preached' truth claims and a set of convictions which they hold dear and regard as essential to their sense of identity. It is not our task to overturn these convictions. Rather, it is our aim to move students from a posture that Transactional Analysis would identify as Child ego-state, that is, beliefs received in the pre-critical phase of life and faith development, dependent on the authority of Parent figures, and move to an Adult ego-state where they embrace and live out their convictions as truly their own. Pedagogy which enables this requires 
a posture of humility on the part of the teacher and a willingness to regard the teacher-student relationship as one of mutuality.

\section{Notes}

1 We would like to acknowledge the help given in writing this paper by Dr David Finch, good friend and tutor in Christian Counselling.

2 For more information see https://scottishbaptistcollege.org/

3 James Wm. McClendon, Jr. and James M. Smith, Convictions: Defusing Religious Relativism (Valley Forge, Pa.: Trinity Press International, 1994) and McClendon's three-volume systematic theology: Ethics (1986), Doctrine (1994), and Witness (2000), all by Nashville, Tenn.: Abingdon Press and recently reprinted by Baylor University Press with a new introduction by Curtis W. Freeman. McClendon's understanding of the theological task would fall into a larger field of a renewed interest in models of theological reflection which seek to heal the rift between 'practical'/applied theology and what has been often implicitly understood as 'proper' (systematic, biblical, philosophical etc.) theology.

4 For an overview, see Curtis W. Freeman, "Introduction: A Theology for Radical Believers and Other Baptists" in McClendon, Ethics, vii-xxxviii (Baylor University Press edition; also included as the introduction to the Doctrine and Witness volumes); Parush R. Parushev, "Convictions and the Shape of Moral Reasoning", in Ethical Thinking at the Crossroads of European Reasoning, ed. Parush R. Parushev, Ovidiu Creangă and Brian Brock (Prague: International Baptist Theological Seminary, 2007), 27-45; Lina Andronoviene, Transforming the Struggles of Tamars: Single Women and Baptistic Communities (Eugene, Or.: Pickwick Publications, 2014), esp. 115-18; David John McMillan, Convictions, Conflict and Moral Reasoning: The Contribution of the Concept of Convictions in Understanding Moral Reasoning in the Context of Conflict, Illustrated by a Case Study of Four Groups of Christians in Northern Ireland (PhD. Diss., Vrije Universiteit Amsterdam, 2019). 
5 McClendon, Ethics, 23.

6 On the role of 'embodied-context' dimensions of ethical reasoning, such as passions, interests and community loyalties, see David Gushee and Glen Stasse, Kingdom Ethics: Following Jesus in Contemporary Context, 2nd ed. (Grand Rapids, Mich.: Eerdmans, 2016), 178-80.

7 Migliore's introduction to theology is a particular challenge to new students as he unpicks this theodicy, calling it 'repulsive and destructive'. Daniel L. Migliore, Faith Seeking Understanding: An Introduction to Christian Theology (Grand Rapids, Mich.; Cambridge: Eerdmans, 2014), 128.

8 McClendon and Smith, Convictions, $7 \mathrm{f}$.

9 Darrell L. Guder, The Continuing Conversion of the Church (Grand Rapids, Mich.; Cambridge: Eerdmans, 2000).

10 For example, the work of ARCS (Action Research: Church and Society) introduced 'four voices' of theology - operant, espoused, formal and normative. Helen Cameron, Deborah Bhatti, Catherine Duce, James Sweeney and Clare Watkins, Talking About God in Practice: Theological Action Research and Practical Theology (London: SCM Press, 2010).

11 See, for example, Meredith B. McGuire, Lived Religion: Faith and Practice in Everyday Life (Oxford: Oxford University Press, 2008).

12 See, for instance, Jeff Astley and Leslie J. Francis, Exploring Ordinary Theology: Everyday Christian Believing and the Church (Aldershot: Ashgate, 2013); Charles Marsh, Peter Slade and Sarah Azaransky, eds., Lived Theology: New Perspectives on Method, Style, and Pedagogy (Oxford: Oxford University Press, 2017). For an overview of different approaches to the relationship between theology and practice, see Pete Ward, Introducing Practical Theology: Mission, Ministry, and the Life of the Church (Grand Rapids, Mich.: Baker Academic, 2017).

13 E.g., Lina Andronoviene, "As Songs Turn Into Life and Life Into Songs: On the First-order Theology of Baptist Hymnody", in Currents in Baptistic Theology of Worship Today, ed. Keith G. Jones and Parush R. Parushev (Prague: International Baptist Theological Seminary, 2007), 129-41; Parush R. Parushev, 
"Carrying Out the Theological Task in a Baptistic Way", Baptistic Theologies 6 (2014): 53-71.

14 Moltmann is particularly critical of the hierarchical 'chain of authority', describing it as keeping 'the people' unaware 'of their immaturity and their lack of control over their own future'. Jürgen Moltmann, The Open Church: Invitation to a Messianic Lifestyle (London: SCM Press, 1978), 99.

15 Alison King, "From Sage on the Stage to Guide on the Side", College Teaching 41 (1993): 30-35.

16 Diane F. Halpern and Milton D. Hakel, "Applying the Science of Learning to the University and Beyond: Teaching for LongTerm Retention and Transfer", Change: The Magazine of Higher Learning 35 (2003): 36-41.

17 For a Handbook co-written by one of the SBC staff, see Lina Andronoviene et al., Academic Reasoning, Research and Writing in Religious Studies: A Concise Handbook, Revised and Enlarged Edition (Prague: International Baptist Theological Seminary, 2014).

18 This pedagogical approach will resonate with those familiar with Freire's liberation education. Freire's pedagogy reconciles the separation between learner and learned with each being 'simultaneously teachers and students'. Paulo Freire, Pedagogy of the Oppressed, trans. Myra Bergman Ramos (St. Ives: Penguin Classics, 2017), 45. At its heart, it breaks down the didactic 'banking' approach to education and advocates for the process to be transformational.

19 Eric Berne, Transactional Analysis in Psychotherapy (New York: Grove Press, 1961); Games People Play: The Psychology of Human Relationships (London: Penguin, 1964). See also Giles Barrow, "Transactional Analysis in the Classroom, Staffroom and Beyond", Pastoral Care in Education 33 (2015): 169-79.

20 Berne, Games People Play, 23-25. Ian Stewart and Vann Joines, TA Today: A New Introduction to Transactional Analysis (Nottingham: Lifespace Publishing, 1987), 18.

21 Berne, Transactional Analysis in Psychotherapy, 77.

22 Ibid., 67. Also Carol Solomon, "Transactional Analysis Theory: The Basics”, Transactional Analysis Journal 33 (2003): 15. 
23 See Richard G. Erskine, "Resolving Intrapsychic Conflict: Psychotherapy of Parent Ego States", in Ego States, ed. Charlotte Sills and Helena Hargaden, Vol. 1 of Key Concepts in Transactional Analysis: Contemporary Views (London: Worth, 2003), 86-90.

24 See, for example, Kaz Stuart and Ali Alger, "The Use of Transactional Analysis in Secondary Education: A Case Study", Teacher Education Advancement Network Journal (TEAN), 3.1 (2001). Available at: https://ojs.cumbria.ac.uk/index.php/TEAN/ index

25 Stewart and Joines, TA Today, $281 \mathrm{f}$.

26 Berne, Games People Play, 26.

27 Ibid., 24. For a discussion of Berne's theory see William F. Cornell, "Babies, Brains and Bodies: Somatic Foundation of the Child", in Sills and Hargaden, Ego States, 28-54.

28 Berne, Transactional Analysis in Psychotherapy, 77.

29 See Holly Joan Toensing, “'Living Among the Tombs': Society, Mental Illness and Self-destruction in Mark 5:1-20", in This Abled Body: Rethinking Disabilities in Biblical Studies, ed. Hector Avalos, Sarah Melcher and Jeremy Schipper (Atlanta: Society of Biblical Literature, 2007), 131-43.

30 Berne, Transactional Analysis in Psychotherapy, 77f. See also Stewart and Joines, TA Today, 23.

31 Stewart and Joines, TA Today, 22f; Berne, Transactional Analysis in Psychotherapy, 78.

32 Stewart and Joines, TA Today, 281.

33 Susannah Temple, "Update in the Functional Fluency Model in Education", Transactional Analysis Journal 34 (2004): 197-204; Barrow, "Transactional Analysis in the Classroom, Staffroom and Beyond", 172f.

34 See Stewart and Joines, TA Today, 281.

35 Ibid., 25.

36 Stewart and Joines, TA Today, 281; cf. Berne, Transactional Analysis in Psychotherapy, 76f.

37 Stewart and Joines, TA Today, 26, 33.

38 Berne, Games People Play, 161.

39 Berne introduces three such capacities: awareness, spontaneity and what he calls 'intimacy'. Games People Play, 158ff. 
40 McClendon, Ethics, 17.

${ }^{41}$ The idea of struggle resonates with Clare Watkins et al., who note the tension between 'lived' (operant) and 'preached' (espoused) theology: "Practical Ecclesiology: What Counts as Theology in Studying the Church?", in Pete Ward, ed., Perspectives on Ecclesiology and Ethnography (Grand Rapids, Mich.; Cambridge: Eerdmans, 2012), 177. 